\title{
Solusi Permasalahan Manajerial di Skills Lab
}

\author{
Atik Maftuhah \\ Laboratorium Skills Lab, Fakultas Kedokteran, Universitas Sebelas Maret \\ Korespondensi : dratikmaftuhah@staff.uns.ac.id
}

\begin{abstract}
ABSTRAK
Pendahuluan: Pembelajaran keterampilan klinis di skills lab memberikan kesempatan mahasiswa untuk belajar dan mempraktikkan keterampilan klinis mahasiswa sebelum terjun ke pasien langsung. Namun, skills lab sendiri memiliki komponen yang banyak sehingga memerlukan manajemen dan leadership yang baik supaya tidak terjadi kendala atau permasalahan dalam pelaksanaan pembelajaran.

Metode: Literature review yang dilakukan melalui search engine google dan google scholar dengan kata kunci "leadership", "management", "team”, dan "skills lab" dari tahun 1985-2015.

Hasil: Ada beberapa konsep dari studi literatur terpilih yang dapat diaplikasikan untuk mengatasi permasalahan manajerial di skills lab. Profil pemimpin/manajer yang efektif menurut Quinn (Quinn's eight roles) sangat diperlukan dalam memimpin skills lab karena kepala bagian skills lab sebagai manajer lini pertama bertanggung jawab terhadap permasalahan manajerial di skills lab. Selain itu, manajemen dan leadership di skills lab juga sangat diperlukan untuk menghasilkan tim yang efektif dan efisien sehingga kinerja dan kontribusi tim pengelola menjadi efektif. Dengan memahami the Belbin Team Roles, maka konsep tersebut dapat diadaptasi dalam pengelolaan manajemen skills lab dengan melakukan sinergi peran diantara anggota tim pengelola skills lab. Dalam konsep tersebut, terdapat delapan aspek peran dalam sebuah tim manajemen yang bagus.

Kesimpulan: Dengan adanya kompleksitas di skills lab, maka dapat timbul permasalahan manajerial seperti kurang siapnya modul, peralatan, fasilitas, dan lainnya. Penyelesaian permasalahan manajerial di skills lab dapat ditinjau dari aplikasi peran dan fungsi manajer, Quinn's eight roles dan the Belbin team roles.
\end{abstract}

Kata kunci : leadership, manajemen, tim, skills lab.

\begin{abstract}
Introduction: Learning clinical skills in the skills lab gives students the opportunity to learn and practice their clinical skills before examining directly to patients. However, the skills lab itself has many components that require good management and leadership to avoid obstacles or problems in the implementation of learning.

Method: Literature review conducted through google and google scholar search engines with the keywords "leadership", "management", "team", and "skills lab" from 19852015.

Result: There are several concepts from literature study that can be applied to overcome managerial problems in the skills lab. An effective leader / manager profile according to Quinn (Quinn's eight roles) is needed in leading the skills lab because the head of the skills lab as the first line manager is responsible for managerial problems in the skills lab. In addition, management and leadership in the skills lab is also very necessary to produce an effective and efficient team so that the performance and contribution of the management team is effective. By understanding the Belbin Team Roles, the concept can be adapted in managing the skills lab management by synergizing the roles among the members of the
\end{abstract}


skills lab management team. Within this concept, there are eight aspects of roles in a good management team.

Conclusion: Given the complexity in the skills lab, managerial problems can arise that can result in the preparation of modules, equipment, facilities, etc. being unprepared. Managerial problem solving in the skills lab can be solved by applying the manager's roles and functions, Quinn's eight roles and the Belbin team roles.

Keyword : leadership; managemen; team; skills lab

\section{PENDAHULUAN}

Perubahan kurikulum pendidikan kedokteran di Indonesia menjadi kurikulum problem based learning (PBL) memiliki dampak perubahan yang besar bagi sebuah institusi pendidikan kedokteran. Salah satu diantaranya yaitu sistem PBL ini mengintegrasikan dan menekankan kembali pelatihan keterampilan klinik ke dalam kurikulum pendidikan kedokteran bagi mahasiswa pre-klinik ${ }^{1}$. Pelatihan keterampilan klinik bagi mahasiswa pre-klinik ini bertujuan untuk mempersiapkan mahasiswa sebelum memasuki rotasi klinik karena mahasiswa yang tingkat kemampuannya masih novice perlu menguasai dasar-dasar prosedur keterampilan klinik sebelum terjun ke pasien langsung ${ }^{2,3}$. Untuk menciptakan lingkungan yang aman untuk belajar dan mempraktekkan keterampilan klinik tersebut, maka saat ini skills lab banyak dikembangkan dalam program pedidikan dokter di seluruh dunia untuk memfasilitasi pembelajaran yang terstruktur dalam mengajarkan keterampilan klinik termasuk pemberian umpan balik dan penilaian untuk menilai kompetensi ${ }^{1,4,5}$.

Keterampilan klinik inti yang diajarkan dan dipelajari melalui skills lab ditentukan oleh kemampuan lokal dan kebutuhan pendidikan, diantaranya yaitu anamnesis dan keterampilan komunikasi, pemeriksaan fisik, serta keterampilan prosedural ${ }^{6}$. Di Indonesia, Standar Kompetensi Dokter Indonesia (SKDI) yang disusun oleh Konsil Kedokteran Indonesia menjadi standar minimal kompetensi lulusan dokter dan daftar keterampilan klinis dalam SKDI dapat dijadikan acuan bagi institusi pendidikan dokter dalam menyiapkan sumber daya yang terampil dan menjadi lulusan dokter yang kompeten ${ }^{7}$. SKDI tersebut menjadi acuan bagi penyusunan kurikulum pembelajaran keterampilan klinik di skills lab sehingga pelatihan keterampilan klinik ini diajarkan mulai sejak awal hingga akhir pendidikan dokter secara berkesinambungan.

Skills lab sendiri memiliki tiga komponen yaitu fasilitas, peralatan khusus, dan staf khusus ${ }^{8}$. Fasilitas meliputi lingkungan dan sarana prasarana untuk melakukan kegiatan skills lab. Fasilitas tersebut meliputi ruang-ruang kecil yang digunakan untuk proses belajar mengajar maupun ujian, ruang penyimpanan peralatan dan manekin, loker, kantor dosen dan staf skills lab, ruang untuk pelatihan pasien standar, ruang seminar, dan lainnya tergantung sumber daya institusi masing-masing. Peralatan khusus merupakan peralatan yang menggunakan teknologi seperti manekin maupun simulator mulai dari lowhingga high-fidelity ${ }^{8}$. Pasien simulasi dapat digunakan pada saat pembelajaran maupun ujian tergantung dari kemampuan institusi juga. Komponen staf khusus terdiri dari para dosen yang memiliki keahlian dalam menggunakan simulasi, memiliki keahlian keterampilan komunikasi, dan juga memiliki ketertarikan dalam mengajar ${ }^{8}$. Para dosen instruktur tersebut juga didukung oleh staf pendukung seperti staf administrasi, koordinator pasien, dan teknisi untuk membantu pelaksanaan kegiatan di skills $l a b^{6,8}$. Dengan banyaknya komponen yang terdapat di skills lab tersebut, maka kegiatan yang berlangsung pada saat sesi belajar 
mengajar maupun penilaian di skills lab merupakan kegiatan yang sangat kompleks dalam pelaksanaannya. Oleh karena itu, manajemen yang sangat bagus sangat diperlukan agar kegiatan rutin yang dilakukan di skills lab dapat berjalan dengan baik.

Skills lab memiliki seorang pemimpin yang bertanggungjawab untuk mengawasi penggunaan fasilitas untuk aktivitas belajar mengajar dan assesmen ${ }^{4}$. Pemimpin di skills $l a b$ inilah yang menjadi manajer lini pertama karena akan berhubungan dengan kegiatan rutin harian yang harus dikelola. Dengan keterbatasan kemampuan masing-masing institusi dalam penyelenggaraan skills lab ini, maka peran manajer dalam hal ini ketua skills lab perlu dimaksimalkan karena dengan manajemen yang kurang bagus, maka dapat mengakibatkan beberapa permasalahan seperti ketidaksiapan modul, peralatan, dan fasilitas, serta dapat menimbulkan keluhan baik dari mahasiswa maupun dosen instruktur/penguji bila terjadi kekurangan dalam pelaksanaan kegiatan di skills lab. Oleh karena itu, perlu dilakukan analisis permasalahan manajerial di skills lab dan rekomendasi dari literatur agar manajemen di skills lab bisa lebih dioptimalkan.

\section{METODE}

Literatur yang relevan digunakan sebagai dasar dalam melakukan review. Pencarian literatur dilakukan melalui search engine google dan google scholar dengan kata kunci leadership, management, team, dan skills lab dari tahun 1985-2015. Penulis memilih beberapa literatur yang sesuai dengan topik yang dibahas.

\section{HASIL}

Berdasarkan kesesuaian dengan topik yang dibahas, terdapat sembilan sumber artikel yang digunakan sebagai dasar penulisan literature review ini. $^{9-17}$

\section{PEMBAHASAN}

\section{Peran dan Fungsi Manajer}

Kotter (2001) mengemukakan bahwa kepemimpinan dan manajemen merupakan dua hal yang berbeda dan merupakan sistem aksi yang saling melengkapi, masing-masing memiliki fungsi dan karakteristik aktivitas tersendiri. Kepemimpinan merupakan kepemilikan dan penggunaan kekuatan untuk membuat perubahan yaitu untuk mempengaruhi pemikiran dan tindakan orang lain $^{10,11}$. Kepemimpinan memiliki elemen inspirasi dan visi yang mengarahkan pada kesuksesan, sedangkan manajer merupakan seorang problem solver, menunggu perintah, melakukan kontrol dan mencari resolusi segera terhadap permasalahan yang $\mathrm{ada}^{11}$. Cuban dalam (Bush, 2008b) menyatakan perbedaan yang jelas antara kepemimpinan dan manajemen, yaitu bahwa kepemimpinan itu terkait dengan perubahan sedangkan manajemen berkaitan dengan aktivitas maintenance. Sama halnya dengan yang dikemukakan oleh Kotter (2001) bahwa kepemimpinan merupakan segala sesuatu yang berkaitan dengan bagaimana menghadapi perubahan, sedangkan manajemen merupakan segala sesuatu yang berkaitan dengan bagaimana menghadapi kompleksitas. Perubahan merupakan hal yang penting untuk bisa bertahan dan bersaing di era jaman seperti sekarang dan perubahan selalu membutuhkan kepemimpinan ${ }^{9}$. Tetapi, tanpa manajemen yang baik, maka organisasi memiliki kecenderungan untuk menjadi chaos atau berantakan ${ }^{9,13}$. Meskipun berbeda, kepemimpinan dan manajemen keduanya sangatlah penting ${ }^{13}$. Bagi institusi pendidikan, keduanya merupakan komponen utama agar institusi dapat berjalan dengan efektif dan dapat mencapai tujuan organisasi serta tujuan pendidikannya.

Perbedaan fungsi keduanya yaitu bagaimana menghadapi kompleksitas dan 
bagaimana menghadapi perubahan karakteristik aktivitas tersebut dapat membentuk karakteristik aktivitas manajemen digambarkan seperti pada tabel 1 di bawah ini dan kepemimpinan'. Adapun perbedaan :

Tabel 1. Perbedaan karakteristik akivitas manajemen dan kepemimpinan ${ }^{9}$

\begin{tabular}{l} 
Manajemen \\
\hline Manajemen mengelola kompleksitas pertama kali \\
dengan melakukan planning dan budgeting - \\
membuat target atau tujuan kedepan (biasanya \\
untuk bulan depan atau tahun depan), menyusun \\
langkah-langkah detail untuk mencapai target \\
tersebut, dan kemudian mengalokasikan sumber \\
daya untuk mencapai perencanaan ini. \\
Manajemen mengembangkan kapasitas untuk \\
mencapai rencana tersebut dengan melakukan \\
organizing dan staffing - menciptakan struktur \\
organisasi dan menyusun pekerjaan untuk bisa \\
mencapai kebutuhan dalam rencana, memilih \\
orang-orang yang memiliki kualifikasi untuk \\
melakukan pekerjaan tersebut, \\
mengkomunikasikan rencana ini kepada orang- \\
orang yang akan terlibat, mendelegasikan \\
tanggungawab untuk melaksanakan rencana, dan \\
membuat sistem untuk memonitor pelaksanaan.
\end{tabular}

Terakhir, manajemen memastikan bahwa rencana yang dibuat sudah terlaksana dengan melakukan controlling dan problem solving - memonitor hasil dibandingkan dengan rencana baik secara formal maupun informal melalui cara-cara seperti laporan, pertemuan, dan cara lain, kemudian bila mengidentifikasi adanya penyimpangan maka akan melakukan planning dan organizing untuk Pemimpin memulai perubahan yang konstruktif dengan membuat sebuah tujuan atau arahan mengembangkan visi ke depan (seringkali visi yang sangat jauh ke depan) bersama strategi untuk menghasilkan perubahan yang diperlukan untuk mencapai visi tersebut.

Aktivitas pemimpin yaitu menyelaraskan atau meluruskan orang-orang, yaitu dengan mengkomunikasikan tujuan atau arah baru kepada orang-orang yang dapat menciptakan koalisi yang dapat mengerti visi.

Dalam mencapai visi tersebut, maka seorang pemimpin akan memberikan motivasi dan insprasi - menjaga orang-orang agar tetap bergerak dalam arah yang benar, meskipun ada tantangan yang besar untuk berubah, dengan memperhatikan hal-hal dasar berupa kebutuhan manusia, nilai-nilai, dan emosi. memecahkan masalah.

\section{Quinn's Eight Roles}

Secara umum, manajer merupakan profil yang menghargai stabilitas, perintah, dan efisiensi, sedangkan leader (pemimpin) lebih menghargai fleksibiltas, inovasi, dan adaptabilitas ${ }^{14}$. Manajer lebih berfokus pada mengoperasikan organisasi sehari-hari sedangkan pemimpin berfokus pada arah masa depan, menatur tujuan dan strategi untuk mencapai tujuan tersebut ${ }^{14}$. Quinn membuat empat model peran manager (open system model, human relations model, internal process model, rational goal model) dan delapan peran (innovator, broker, producer, director, coordinator, monitor, facilitator, mentor) untuk menganalisis kemampuan manager yang dibutuhkan agar organisasi berjalan secara efisien ${ }^{14}$. 


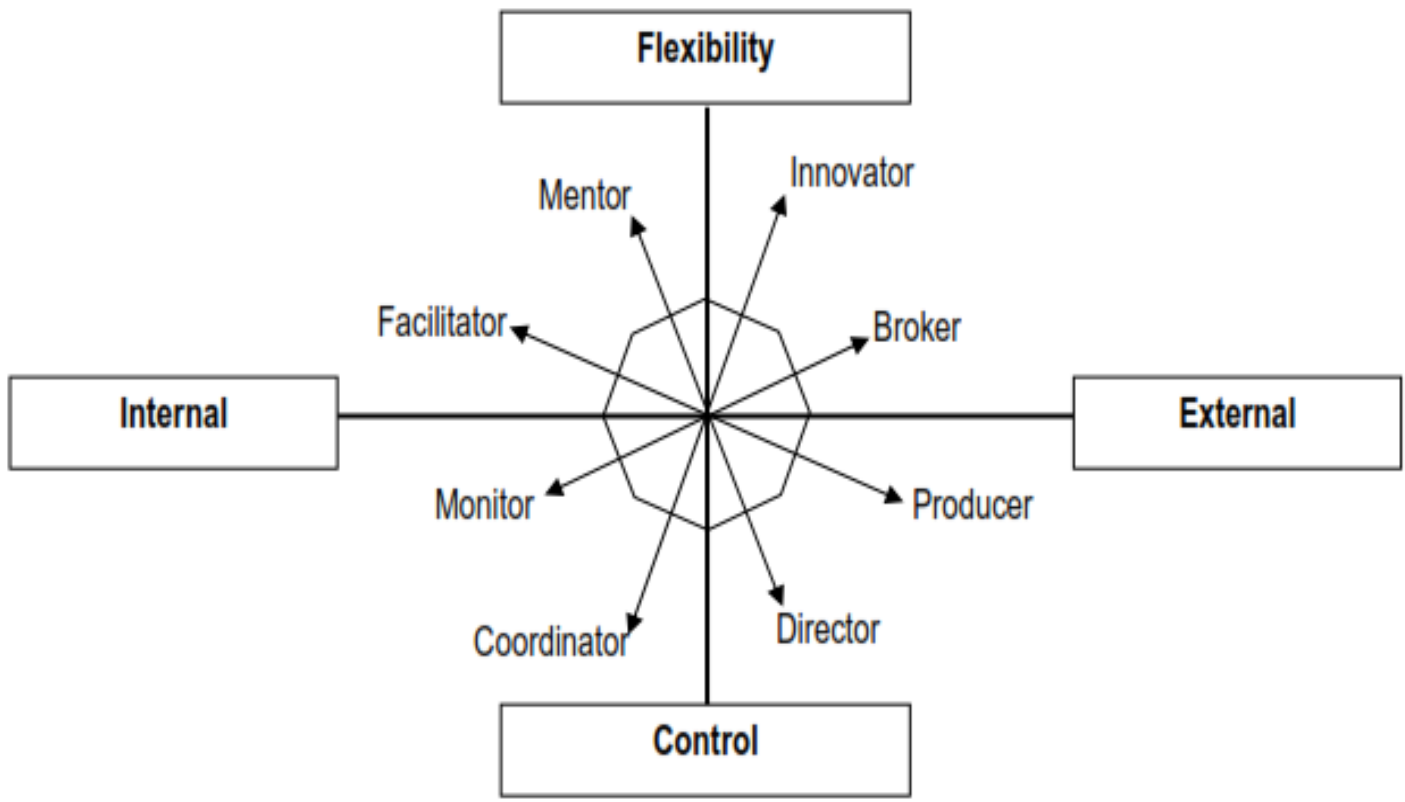

Gambar 1. Kerangka nilai dan peran yang saling berkompetisi Quinn ${ }^{14}$

Dalam kerangka pada gambar 1 tersebut, maka aksis horizontal terdiri dari sistem kontrol yang berkompetisi dengan sistem yang fleksibel, sedangkan aksis vertikal terdiri dari sistem yang lebih berfokus secara internal yang berkompetisi dengan sistem yang berfokus secara eksternal ${ }^{14}$. Masing-masing kuadran memiliki dua peran yang mendeskripsikan perilaku yang dapat dimiliki oleh manajer atau pemimpin, dimana peran tersebut memiliki peran yang berkompetisi dari kuadran yang saling berlawanan.

- Kuadran internal-fleksibel (human relations model) : peran mentor dan fasilitator. Mentor berarti memahami orang lain, berkomunikasi secara efektif, dan meningkatkan pengikutnya, sedangkan fasilitator berarti membangun tim yang efektif, memfasilitasi pengambilan keputusan yang partisipatif dan mengelola konflik dengan baik.

- Kuadran eksternal-kontrol (rational goal model) : merupakan peran yang berkompetisi dengan kuadran internalfleksibel. Producer berperan dalam bekerja secara produktif, mengelola waktu dan stres, dan menumbuhkan lingkungan kerja yang produktif, sedangkan director berperan dalam mendesain dan mengorganisasi pekerjaan termasuk melakukan delegasi dan mengatur tujuan.

- Kuadran internal-kontrol (internal process model) : peran monitor terdiri dari melakukan monitor kinerja individu dan organisasi, sedangkan peran koordinator yaitu mengelola proses pekerjaan.

- Kuadran eksternal fleksibel (open system model) : merupakan peran yang berkompetisi dengan kuadran internalkontrol. Peran sebagai innovator yaitu menumbuhkan lingkugan yang kreatif dan menciptakan perubahan yang kreatif, sedangkan peran broker yaitu membangun dan mempertahankan kekuatan dasar, mengungkapkan ide-ide, dan melakukan negosiasi kesepakatan serta komitmen ${ }^{14}$.

Berdasarkan kerangka peran yang sudah dijelaskan di atas, Quinn dalam Kinghorn et al. (2007) memberikan detail profil pemimpin/manajer yang efektif dan tidak efektif pada tabel 2 sebagai berikut : 
Tabel 2. Profil pemimpin/manajer menurut Quinn

\begin{tabular}{|c|c|}
\hline Profil pemimpin/manajer yang efektif: & Profil pemimpin/manajer yang tidak efektif: \\
\hline the Master Manager : seimbang di semua skill & $\begin{array}{l}\text { the Drowning Workaholic : lemah di segala } \\
\text { hal kecuali kuat dalam hal producer }\end{array}$ \\
\hline $\begin{array}{l}\text { the Conceptual Producer : lemah dalam } \\
\text { monitor dan koordinator, tetapi kuat dalam } \\
\text { produksi dan inovasi }\end{array}$ & $\begin{array}{l}\text { the Chaotic Adaptive : kuat sebagai fasilitator, } \\
\text { mentor, inovator, tetapi lemah di peran lain }\end{array}$ \\
\hline $\begin{array}{l}\text { the Peacefull Team Builder : lemah sebagai } \\
\text { producer dan broker, tetapi kuat sebagai } \\
\text { fasilitator }\end{array}$ & $\begin{array}{l}\text { the Abrasive Coordinator: kuat dalam } \\
\text { monitor dan koordinator tetapi lemah di peran } \\
\text { lain }\end{array}$ \\
\hline $\begin{array}{l}\text { the Aggressive Achiever : sedikit lemah sebagai } \\
\text { fasilitator, tetapi kuat sebagai producer }\end{array}$ & $\begin{array}{l}\text { the Extreme Unproductive : lemah di segala } \\
\text { hal, tetapi kuat dalam hal mentoring dan } \\
\text { paling lemah dalam hal producing }\end{array}$ \\
\hline
\end{tabular}

\section{The Belbin Team Roles}

Kepala bagian skills lab sebagai manajer lini pertama bertanggung jawab terhadap permasalahan manajerial di skills lab. Masalah ini berkaitan dengan pelaksanaan tugas sehari-hari untuk mencapai tugas yang sudah ditetapkan. Agar dapat menyelesaikan tugas dengan efektif dan efisien serta tepat waktu, maka diperlukan tim yang memiliki kontribusi atau kinerja dengan menggunakan konsep the Belbin team roles yang dikemukan oleh Belbin (2010) dalam buku Management Team. Dalam konsep tersebut, terdapat delapan aspek peran dalam sebuah tim manajemen yang bagus. Deskripsi karakteristik masing-masing peran dalam tim ini dapat dilihat dalam tabel 3.

Pada pengembangan berikutnya, Belbin (1988) memampatkan delapan peran tersebut menjadi empat dengan mengkombinasikan peran yang terdahulu menjadi seperti di bawah ini :
Resource investigator + Team worker $=>$ Negotiator role

Implementer + Completer-Finisher $=>$ Manager/team worker role

Plant + Monitor/evaluator $=>$ Intellectual role

Co-ordinator + Shaper $=>$ Team leader role

Belbin team role self-perception inventory (BTR-SPI) sudah digunakan secara luas di dunia industri dan bisnis, terutama dalam hal pengembangan tim manajemen, dalam konseling dan seleksi, serta sering digunakan pula sebagai alat dalam program pelatihan manajemen ${ }^{16}$. Dengan memahami the Belbin Team Roles, maka konsep tersebut dapat diadaptasi dalam pengelolaan manajemen skills lab dengan melakukan sinergi peran diantara anggota tim pengelola skills lab. Masing-masing anggota tim pengelola skills lab mungkin saja memiliki lebih dari satu peran pada konsep the Belbin Team Roles sehingga dapat tumpang tindih dengan peran anggota tim yang lain. Oleh karena itu, perlu kesinambungan yang baik dari masing-masing peran anggota tim dan semua peran harus ada di dalam tim tersebut sehingga bisa menghasilkan manajemen yang bagus. 
Tabel 3. Delapan komponen Belbin Team Roles ${ }^{16}$

\begin{tabular}{|c|c|}
\hline Peran & Karakteristik \\
\hline Plant & $\begin{array}{l}\text { Membantu mengembangkan ide-ide dan strategi baru. Berusaha } \\
\text { menyelesaikan masalah yang dihadapi dengan berkonsentrasi pada } \\
\text { permasalahan-permasalahan yang besar dan melupakan hal-hal yang } \\
\text { detail. }\end{array}$ \\
\hline $\begin{array}{l}\text { Resource } \\
\text { investigator }\end{array}$ & $\begin{array}{l}\text { Mengeksplorasi dan melaporkan pengembangan ide dan sumber daya } \\
\text { di luar tim, menciptakan hubungan eksternal yang dapat bermanfaat } \\
\text { bagi tim. Pada umumnya merupakan orang yang ekstrovert, antusias, } \\
\text { ingin tahu, dan merupakan komunikator yang handal. }\end{array}$ \\
\hline Co-ordinator & $\begin{array}{l}\text { Memiliki kemampuan menggerakkan seluruh anggota tim untuk } \\
\text { bekerja mencapai sasaran. Pada umumnya merupakan seseorang yang } \\
\text { matang, dapat dipercaya dan juga percaya diri. Sangat bagus } \\
\text { ditempatkan pada posisi yang bertanggungjawab terhadap sebuah tim } \\
\text { yang memiliki berbagai keterampilan dan karakteristik personal. }\end{array}$ \\
\hline Shaper & $\begin{array}{l}\text { Membantu mengarahkan tim, mengidentifikasi hal-hal yang menjadi } \\
\text { fokus utama tim, menyusun tujuan dan memprioritaskan pekerjaan. }\end{array}$ \\
\hline Monitor/evaluator & $\begin{array}{l}\text { Pada umumnya memiiki pembawaan yang serius, suka menganalisis } \\
\text { masalah dan mengevaluasi ide-ide. Peran ini dapat memberikan } \\
\text { pendekatan yang seimbang antara ide-ide dan mencegah tim agar } \\
\text { tidak membuat keputusan yang tidak terarah. }\end{array}$ \\
\hline Team worker & $\begin{array}{l}\text { Membantu mendukung anggota tim lain ketika ada anggota tim yang } \\
\text { berhalangan atau dalam kondisi tidak dapat bekerja. Mereka sangat } \\
\text { peduli terhadap kebuthan dan kecemasan anggota tim yang lain dan } \\
\text { secara aktif membantu komunikasi di dalam grup untuk menciptakan } \\
\text { harmoni, kesejahteraan, dan semangat kerja. }\end{array}$ \\
\hline Implementer & $\begin{array}{l}\text { Memiliki kontrol diri, disiplin, suka bekerja keras, dan mengatasi } \\
\text { masalah. Memiliki kemampuan mengaplikasikan rencana kerja. } \\
\text { Bekerja secara efektif dan efisien. }\end{array}$ \\
\hline Completer-Finisher & $\begin{array}{l}\text { Berperan dalam membantu mendetailkan kinerja tim, melindungi tim } \\
\text { dari kesalahan dan kekurangan. Memiliki konsentrasi yang tinggi dan } \\
\text { atensi terhadap hal-hal yang bersifat mendesak. }\end{array}$ \\
\hline
\end{tabular}


Langkah pertama untuk menyelesaikan permasalahan manajerial di skills lab adalah mengidentifikasi penyebab terjadinya permasalahan. Perencanaan dan pembagian tugas di skills lab harus jelas, didukung dengan ketua skills lab sebagai manajer lini pertama seharusnya mampu melakukan fungsi dan perannya sebagai manajer sehingga dosen dan staf pengelola skills lab yang ada di bawahnya melakukan pekerjaan sehari-hari merasakan adanya fasilitasi maupun evaluasi. Jika ada permasalahan yang terjadi, maka peran manajer sebagai problem solver dirasa masih kurang. Kinerja tim yang ada akhirnya menghasilkan suatu manajemen yang belum benar-benar baik. Oleh karena itu, untuk mempersiapkan modul, fasilitas, dan peralatan yang digunakan untuk pembelajaran di skills lab, maka perlu penyelesaian masalah manajerial agar kegiatan yang direncanakan bisa berjalan dengan baik dan lancar. Berdasarkan rekomendasi literatur, maka yang dapat dioptimalkan dalam mempersiapkan kegiatan yang akan berlangsung di skills lab antara lain :

1. Memastikan aktivitas manajerial untuk mengelola sebuah kompleksitas atau problem solving dilakukan langkah demi langkah, fokus terhadap fungsi, tugas, dan perilaku.

- Planning merupakan suatu proses manajemen yang dilakukan pertama kali yang didesain untuk mencapai hasil yang diharapkan ${ }^{9}$. Strategi pengembangan skills lab merupakan proses yang meliputi pertimbangan siapa yang akan menggunakan skills lab, keterampilan apa yang akan diajarkan (dan kapan), serta mengidentifikasi peralatan dan sumber daya untuk meningkatkan proses belajar mengajar ${ }^{1}$. Oleh karena itu, dalam proses perencanaan ini yang perlu diperhatikan adalah keterampilan klinik baru apa yang akan diajarkan dalam dua bulan kedepan yang tentunya hal ini merupakan rekomendasi dari tim kurikulum, misalnya keterampilan pemasangan Nasogastric Tube (NGT) untuk mahasiswa semester 4. Kemudian hal selanjutnya adalah mengidentifikasi peralatan yang dibutuhkan : manekin pemasangan NGT, peralatan pemasangan NGT (selang NGT dengan berbagai ukuran, meja steril, cawan bengkok, stetoskop, penlight, tongue spatel, spuit 50-100 cc, gunting, klem, perlak, handscoen steril), serta bahan habis pakai yang diperlukan. Setelah itu, mengidentifikasi sumber daya untuk meningkatkan proses belajar mengajar : jumlah instruktur yang dibutuhkan, seorang pakar yang bertugas sebagai penanggungjawab topik serta memberikan kuliah pengantar bagi mahasiswa, staf pendukung seperti staf administrasi, laboran, dan teknisi. Fasilitas ruang dan sarana prasarana yang dibutuhkan baik untuk kuliah pengantar, kegiatan pelatihan pertemuan sesi pertama dan kedua, kegiatan mandiri mahasiswa, serta kegiatan OSCE juga perlu direncakan agar pada saat pelaksanaan sudah siap. Selain itu, buku modul sebagai panduan mahasiswa juga harus dipersiapkan. Materi pendukung dan petunjuk ini dapat membantu mahasiswa untuk berlatih dengan benar dan hati-hati ${ }^{1}$. Perlu dibuat tenggat waktu perencanaan (jadwal, deadline) agar target tercapai tepat waktu.

- Hal yang perlu dipersiapkan selanjutnya adalah budgeting. Pembiayaan dan costs yang harus dipertimbangkan adalah biaya kapital dan operasional termasuk biaya administratif, kesekretariatan, gaji staf 
teknik, gaji bagi para instruktur pengajar, biaya lain untuk program maintenance dan pembelian peralatan, biaya perjalanan bagi pasien simulasi, serta biaya pengembangan staf dan pasien serta mahasiswa ${ }^{1}$. Dalam hal ini, berarti yang harus direncanakan dan dipersiapkan adalah rencana anggaran dan term of reference (TOR) kegiatan yang akan dilaksanakan dengan memasukkan biaya perkiraan anggaran yang diperlukan seperti biaya pembuatan dan percetakan modul keterampilan klinik, kegiatan training of instructor (TOI), kegiatan pelaksanaan keterampilan termasuk pengadaan bahan habis pakai dan peralatan, kesekretariatan, kegiatan review soal ujian OSCE, dan juga perencanaan anggaran kegiatan OSCE di akhir semester.

- Untuk mencapai rencana yang sudah disusun tersebut, maka langkah selanjutnya yaitu dengan melakukan organizing dan staffing agar dapat mengimplementasikan rencana secara tepat dan seefisien mungkin. Pada tahap ini, struktur pekerjaan harus dibuat terlebih dahulu, kemudian baru mencari orang yang tepat yang cocok dengan pekerjaan yang sudah ditentukan tadi; memberikan atau memfasilitasi pelatihan bagi yang membutuhkan, mengkomunikasikan rencana yang sudah dibuat kepada seluruh anggota, dan memutuskan seberapa banyak otoritas yang akan didelegasikan dan kepada siapa dan membuat sistem untuk memonitor implementas ${ }^{9}$. Manajer bertugas menentukan pekerjaan apa saja yang akan dilakukan oleh tim sesuai dengan perencanaan, kemudian membagi tugas tersebut dengan menempatkan orang yang sesuai dengan tugas pekerjaan tersebut, misalnya tim pembuat modul, anggaran dan TOR, mempersiapkan fasilitas dan peralatan, administrasi, membuat jadwal, dan yang lain. Setelah itu dilakukan komunikasi rencana kepada semua anggota yang terlibat dan menyusun timeline bersama sebagai salah satu cara untuk melakukan monitor seberapa jauh pelaksanaan tugas yang diberikan. Sehingga, sedapat mungkin timeline yang sudah disepakati bersama dapat berjalan dengan semestinya agar target dua bulan bisa tercapai semua persiapan pelatihan keterampilan klinik yang baru. Beberapa pelatihan dapat diberikan bagi anggota tim yang membutuhkan, seperti pelatihan penyusunan modul, pelatihan TOI, dan pelatihan maintenance manekin serta peralatan skills lab.

- Terakhir, manajemen memastikan bahwa rencana yang dibuat sudah terlaksana dengan melakukan controlling dan problem solving. Hasil pekerjaan tim dikontrol dan dibandingkan dengan rencana yang sudah disusun, bisa melalui pertemuan rapat atau secara informal berdasarkan laporan. Bila ada yang mengalami kesulitan atau permasalahan, maka dapat segera mencari solusi untuk memecahkan masalah. Tujuan keseluruhan dari sistem dan struktur adalah untuk membantu orang-orang dengan cara yang normal untuk menyelesaikan pekerjaan rutinitasnya dengan sukses, hari demi hari ${ }^{9}$.

2. Melakukan sinergi peran diantara anggota tim yang terlibat dalam persiapan pelatihan keterampilan klinik yang baru sesuai dengan konsep the Belbin Team Roles. Untuk menghasilkan manajemen yang bagus, maka 
sebaiknya semua peran yang ada dalam konsep the Belbin Team Roles dimiliki oleh tim.

3. Prinsip-prinsip kepemimpinan pada pendidikan tinggi menurut Paul Ramsden memiliki kedua elemen baik kepemimpinan dan manajemen ${ }^{10}$. Oleh karena itu, untuk menyelesaikan permasalahan yang ada tentunya tidak hanya memerlukan manajemen yang bagus, tetapi juga membutuhkan seorang pemimpin yang mampu memberikan motivasi dan inspirasi agar dalam mencapai visi dapat memberikan energi bagi orang-orang. Pemimpin merupakan orang yang membuat tujuan, motivasi, dan menggerakkan orang lain, sedangkan manajer mengelola susunan organisasional yang ada secara efektif dan efisien $^{13}$. Seorang manajer merupakan seseorang yang memiliki otoritas dalam posisi formal sedangkan seorang pemimpin bisa saja berasal dari orang yang tidak memiliki peran manajemen yang formal. Melalui motivasi dan inspirasi dari seorang pemimpin, maka semua anggota tim akan bersemangat dalam menjalankan tugasnya masing-masing. Oleh karena itu, peran pemimpin dalam permasalahan ini juga sangat dibutuhkan. Motivasi dapat diberikan dengan memberikan kepuasan bagi orangorang saat melakukan pencapaian tugas yaitu dengan memenuhi kebutuhan dasar sebagai manusia, perasaan memiliki, mendapatkan perhatian atau pengakuan, kepercayaan diri, dan beberapa hal lain yang dapat menyetuh perasaan secara dalam dan dapat menumbuhkan respon yang kuat 9 . Pemimpin yang baik dapat mengenali dan memberikan reward terhadap kesuksesan, yang tidak hanya akan memberikan seseorang perasaan sudah menyelesaikan tugas dengan baik tetapi juga membuat mereka merasa bahwa mereka merupakan bagian dari organisasi yang peduli terhadap mereka sehingga pada akhirnya, hal tersebut akan memberikan motivasi intrinsik dalam melakukan pekerjaannya ${ }^{9}$. Jika dirasa tidak bisa memberikan reward berupa insentif finansial, setidaknya sebagai seorang pemimpin yang baik maka dapat memberikan kompensasi yang sesuai dengan pencapaian kerja tim yang ada, seperti memberikan dukungan perhatian atau pengakuan sehingga anggota tim merasa dipedulikan.

4. Kemampuan seorang pemimpin atau manajer yang efektif sesuai dengan Quinn's eight roles diperlukan agar institusi berjalan dengan baik. The Master Manager role merupakan karakteristik pemimpin atau manajer yang seimbang dalam menggunakan semua delapan peran Quinn dalam konteks yang tepat ${ }^{14}$. Akan tetapi, masih ada beberapa karakteristik pemimpin atau manajer yang efektif lainnya sehingga setidaknya sebagai manajer lini pertama di skills lab, peran ketua skills lab dapat dimaksimalkan agar tidak menjadi pemimpin atau manajer yang tidak efektif.

\section{KESIMPULAN}

Kurikulum pendidikan kedokteran di Indonesia mengintegrasikan dan menekankan kembali pelatihan keterampilan klinik ke dalam kurikulum pendidikan kedokteran bagi mahasiswa pre-klinik melalui pelatihan keterampilan klinik di skills lab. Dengan banyaknya komponen yang terdapat di skills $l a b$, maka kegiatan yang berlangsung pada saat sesi belajar mengajar maupun penilaian di skills lab merupakan kegiatan yang sangat kompleks dalam pelaksanaannya sehingga diperlukan persiapan yang matang. Dalam mengelola pelatihan keterampilan klinik yang baru, dapat 
timbul permasalahan manajerial yang mengakibatkan persiapan modul, peralatan dan fasilitas menjadi belum siap. Penyelesaian masalah tersebut dapat ditinjau dari peran dan fungsi manajer, Quinn's eight roles dan the Belbin team roles.

\section{DAFTAR PUSTAKA}

1. Boulay, C. \& Medway, C. The clinical skills resource: a review of current practice. Med. Educ 1999; 33, 185-191.

2. Peeraer, G. et al. Clinical Skills Training in a Skills Lab Compared with Skills Training in Internships: Comparison of Skills Development Curricula. Educ. Health 2007; 20(3): 125.

3. Kneebone, R. \& Nestel, D. Learning clinical skills - the place of simulation and feedback. Clin. Teach 2005; 2(2).

4. Corbett, E. C. \& Whitcomb, M. The AAMC Project on the Clinical Education of Medical Students: Clinical Skills Education. Washington DC: The Association of American Medical Colleges; 2004.

5. Lynagh, M., Burton, R. \& Sanson-fisher, R. A systematic review of medical skills laboratory training: Where to from here? A systematic review of medical skills laboratory. Med. Educ 2007; 41, 879-887.

6. Al-Elq, A. Medicine and Clinical Skills Laboratories. J.ournal Fam. Community Med 2007; 14, 1-8.

7. Konsil Kedokteran Indonesia. Standar Kompetensi Dokter Indonesia. Jakarta: Konsil Kedokteran Indonesia; 2012.

8. Ker, J. Clinical skills centre teaching. Dalam: Dent, JA dan Harden RM, editor. A Practical Guide for Medical Teachers. Churchill Livingston; Elsevier; 2013: 75-83.

9. Kotter, J. P. What leaders really do. Harvard Business Review (December); 2001.

10. Parsell, G. \& Bligh, J. Encouraging educational leadership. Med. Educ 2000; 34, 199-200.

11. Zaleznik, A. Managers and leaders: Are they different? Harv. Bus. Rev. 141; 1992: 1-11.

12. Bush, T. The Importance of Leadership and Management for Education. SAGE Publications Ltd.; 2008a.
13. Bush, T. From management to leadership: Semantic or meaningful change? Educ. Manag. Adm. Leadersh. 2008b; 36, 271-288.

14. Kinghorn, B. H., Black, J. \& Oliver, R. Leadership roles and organizational envirotment: relationship between competing values framework leader roles and the context for learning. 2007; 526-534

15. Belbin, R. Management Teams. London: Routledge; 2010.

16. Broomfield, D. \& Bligh, J. Curriculum change : the importance of team role. Med. Educ 199; 31, 109-114.

17. Belbin, R.M. Interplace: Matching people to jobs. Cambridge: Belbin Associates; 1988. 